\title{
Do pneumococcal conjugate vaccines provide any cross-protection against serotype 19A?
}

\author{
William P Hausdorff*, Bernard Hoet, Lode Schuerman
}

\begin{abstract}
Background: Introduction of the 7-valent pneumococcal conjugate vaccine (7vCRM) in several countries has led to a rapid, significant drop in vaccine-type invasive pneumococcal disease (IPD) in immunized children. In the United States and some other countries with high antibiotic use, a subsequent rise in serotype 19A IPD has been taken to indicate that the $19 \mathrm{~F}$ conjugate in the vaccine provides no cross-protection against the immunologically related $19 \mathrm{~A}$.

Discussion: We systematically assessed the clinical efficacy and effectiveness of 19F-containing vaccines against 19A disease or nasopharyngeal carriage by searching English-language articles in the electronic databases PubMed, Current contents, Scopus, and Embase from 1985 to 2008. The vaccine efficacy and effectiveness point estimates were consistently positive for modest protection against 19A IPD and acute otitis media (AOM). However, statistical significance was not reached in any individual study. No consistent impact of 7vCRM on 19A nasopharyngeal colonization could be detected. These findings are discussed in context of immunogenicity analyses indicating that $7 \mathrm{VCRM}$ induces functionally active anti-19A antibodies after the booster dose, and that other 19F-containing vaccine formulations may elicit higher levels of such antibodies after both primary and booster doses.

Summary: Taken together, these results suggest that 19F-conjugates can provide some protection against 19A disease. The magnitude of this protection in a given setting will likely depend on several factors. These include the anti-19A immunogenicity of the specific vaccine formulation, the number of doses of that formulation needed to elicit the response, and the burden of 19A disease that occurs after those doses. It is possible that a modest protective effect may be obscured by the presence of countervailing selection pressures (such as high antibiotic use) that favor an increase in colonization with antibiotic-non-susceptible strains of $19 \mathrm{~A}$.
\end{abstract}

\section{Background}

Since the 7-valent pneumococcal conjugate vaccine (7vCRM; Prevenar ${ }^{\mathrm{rm}} /$ Prevnar $^{\mathrm{mm}}$; Wyeth Vaccines) was first introduced in the United States (US) in 2000, invasive pneumococcal disease (IPD) due to Streptococcus pneumoniae vaccine-serotypes $(4,6 \mathrm{~B}, 9 \mathrm{~V}, 14,18 \mathrm{C}, 19 \mathrm{~F}$, and 23F) has dramatically decreased among children and adults [1-6].

Serotypes 6A and 19A were not included in 7vCRM and several other pneumococcal conjugate vaccines (PCVs) because it was anticipated that the immunological similarities of vaccine serotypes $6 \mathrm{~B}$ and $19 \mathrm{~F}$, respectively, might elicit sufficient cross-protection [7]. There is now convincing evidence that the $6 \mathrm{~B}$ conjugate contained in $7 \mathrm{vCRM}$ (in which the $6 \mathrm{~B}$ polysaccharide is

\footnotetext{
* Correspondence: william.p.hausdorff@gskbio.com

GlaxoSmithKline Biologicals, Rixensart, Belgium
}

conjugated to a non-toxic variant of diphtheria toxin) provides a high degree of cross-protection against $6 \mathrm{~A}$ IPD [8,9], acute otitis media (AOM) [10], and even offers a significant level of herd protection [8]. An efficacy trial with the $11 \mathrm{Pn}-\mathrm{PD}$ vaccine candidate (in which $6 \mathrm{~B}$ was conjugated to the non-typeable Haemophilus influenzae protein $\mathrm{D}$ ) also suggested cross-protection against 6A AOM [11].

For serotype 19A, some preclinical studies support the possibility of cross-protection. For instance, serum from infants immunized with a $19 \mathrm{~F}$ tetanus toxoid conjugate provided protection against lung infection caused by both $19 \mathrm{~F}$ and 19A in a murine model [12]. Nonetheless, clear clinical evidence of cross-protection against 19A disease by $19 \mathrm{~F}$-containing PCVs has been lacking. Indeed, the rise in 19A IPD in certain populations well immunized with 7vCRM would seem to argue against it
C Biomed Central

(c) 2010 Hausdorff et al; licensee BioMed Central Ltd. This is an Open Access article distributed under the terms of the Creative Commons Attribution License (http://creativecommons.org/licenses/by/2.0), which permits unrestricted use, distribution, and reproduction in any medium, provided the original work is properly cited. 
[1-6]. In the US, for example, the incidence of 19A IPD rose in children $>5$ from approximately 2.5 cases/ 100,000 in $1998-9$ (prior to $7 \mathrm{vCRM}$ ) to 9 cases $/ 100,000$ in 2005 [5].

However, analysis of clinical and post-licensure studies with 7vCRM and other pneumococcal conjugate vaccines suggests a more complex situation. This review discusses the literature on cross-protection against 19A disease and colonization provided by $19 \mathrm{~F}$-containing vaccines, and relates these results to recently published immunogenicity data.

\section{Discussion}

\section{Clinical efficacy and effectiveness data}

Table 1 presents a review of prospective and retrospective clinical studies and post-licensure surveillance studies with 7vCRM and other 19F-containing vaccines. We wish to highlight two findings. First, in every analysis with 5 or more 19A cases (Figure 1), the anti-19A point estimate is positive, with values ranging from $13 \%$ to $67 \%$. This suggests that the true efficacy or effectiveness is probably not null. Secondly, however, none of the anti-19A efficacy or effectiveness point estimates is, by itself, statistically significant.

There is considerable variability in the point estimates in Table 1, which could conceivably be related to the different numbers of vaccine doses received by children in each study. There is support for this concept for $6 \mathrm{~B}$ and 6A. Dagan et al., showed that whereas three primary doses (at 2,4, and 6 months of age) of 7vCRM significantly decreased both $6 \mathrm{~B}$ and $6 \mathrm{~A}$ nasopharyngeal colonization as measured in the $2^{\text {nd }}$ year of life, two primary doses alone ( 4 and 6 months) decreased $6 \mathrm{~B}$ but not $6 \mathrm{~A}$ colonization [13].

Two of the studies in Table 1 may provide some insight here. First, the analysis with the lowest point estimate for 19A cross-protection (13\% [95\% confidence intervals, $-79 \%$ to $58 \%$ ]) is a weighted meta-analysis [14] of four randomized, double-blind, placebo-controlled, efficacy studies using 7vCRM $[15,16]$ or the related 9vCRM vaccine $[17,18]$. Twenty six of the $2819 \mathrm{~A}$ cases included in this analysis were contributed by the two 9vCRM studies conducted in Africa in which no booster dose was given.

Also potentially supporting the importance of a booster dose is the heterogeneous post-marketing experience with 19A in the US. The original report on the impact of $7 \mathrm{vCRM}$ introduction in the US pointed to a $40 \%$ ( $\mathrm{p}=$ 0.09 ) decrease in the incidence of serotype 19A IPD in children younger than 2 years of age between the pre7vCRM years 1998-1999 and the first full post-7vCRM year 2001 [19]. This decrease contrasts with the rise in 19A disease detected starting in 2002 in the same active surveillance system [3] and which continued for several years [5]. The onset of the rise coincided with the severe shortage of 7vCRM in the US between 2001 and 2004 that resulted in many children receiving fewer than three primary doses and/or no booster dose [20].

In contrast to the IPD and AOM data summarized in Table 1, there does not appear to be evidence of a consistent 7vCRM effect on 19A colonization itself (Table 2 ), even among different analyses within the same vaccine study population [21-23]. In fact, in some 7vCRM carriage studies at certain ages or time points, an

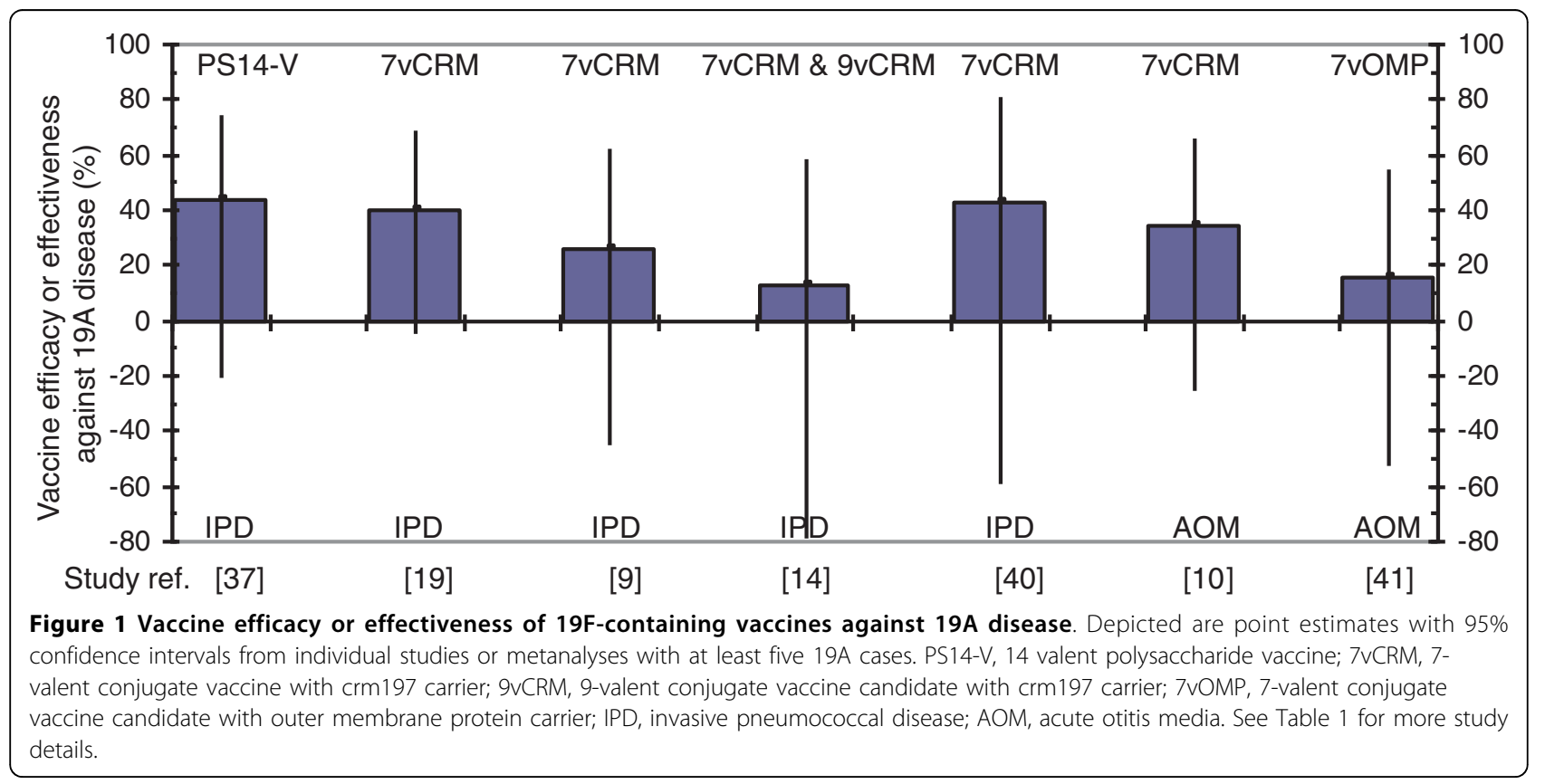


Table 1 Studies examining efficacy or effectiveness of 19F-containing vaccines against 19A IPD and AOM

\begin{tabular}{|c|c|c|c|c|c|c|c|c|c|}
\hline $\begin{array}{l}\text { Study or } \\
\text { Analysis }\end{array}$ & Vaccine & $\begin{array}{l}\text { Vaccine } \\
\text { regimen }\end{array}$ & Endpoint & $\begin{array}{l}\text { Age } \\
\text { group }\end{array}$ & $\begin{array}{l}\text { Total } \\
\text { Number } \\
\text { of } \\
\text { Subjects }\end{array}$ & $\begin{array}{l}\text { Numbers } \\
\text { of } 19 \mathrm{~F} \\
\text { Cases }\end{array}$ & $\begin{array}{l}\text { \% VE against 19F } \\
(95 \% \mathrm{Cl})\end{array}$ & $\begin{array}{l}\text { Numbers } \\
\text { of } 19 \mathrm{~A} \\
\text { Cases }\end{array}$ & $\begin{array}{l}\% \text { VE against } \\
19 \mathrm{~A} \\
(95 \% \mathrm{Cl})\end{array}$ \\
\hline \multicolumn{3}{|c|}{ Polysaccharide vaccine } & IPD & & & & & & \\
\hline $\begin{array}{l}\text { US indirect } \\
\text { cohort analysis } \\
{[37]} \\
\end{array}$ & PS14-V* & $\begin{array}{l}1 \text { dose as per } \\
\text { US recomm. }\end{array}$ & IPD & $>5 y$ & $\begin{array}{l}2837 \text { total } \\
\text { cases }\end{array}$ & $\begin{array}{l}12 \text { (vacc) } \\
32 \text { (unvacc) }\end{array}$ & $\begin{array}{l}11 \\
(-86,56)\end{array}$ & $\begin{array}{l}10 \text { (vacc) } \\
42 \text { (unvacc) }\end{array}$ & $\begin{array}{l}44 \\
(-21,74)\end{array}$ \\
\hline \multicolumn{3}{|c|}{ Conjugate vaccines } & $\mathrm{IPD}$ & & & & & & \\
\hline $\begin{array}{l}\text { N. California } \\
\text { Kaiser } \\
\text { Permanente } \\
\text { efficacy }[15,38]^{\text {a }}\end{array}$ & $7 \vee C R M$ & $2,4,6,12-15 \mathrm{mo}$ & $\begin{array}{l}\text { IPD after } \\
\geq 3 \\
\text { doses }\end{array}$ & $\begin{array}{l}2 \mathrm{mo} \\
\text { to } \sim 3.5 \\
y\end{array}$ & $\begin{array}{l}18927 \\
\text { (vacc) } \\
18941 \\
\text { (ctrl) }\end{array}$ & $\begin{array}{l}2 \text { (vacc) } \\
13 \text { (ctrl) }\end{array}$ & $\begin{array}{l}85 \\
(32,97)\end{array}$ & $\begin{array}{l}0 \text { (vacc) } \\
1 \text { (ctrl) }\end{array}$ & $\begin{array}{l}67 \\
(-719,99)\end{array}$ \\
\hline $\begin{array}{l}\text { Native Americans } \\
\text { efficacy }[16,38]^{a}\end{array}$ & 7VCRM & $2,4,6,12-15 \mathrm{mo}$ & $\begin{array}{l}\text { IPD after } \\
\geq 3 \\
\text { doses }\end{array}$ & $\begin{array}{l}2 \mathrm{mo} \\
\text { to } 2 \mathrm{y}\end{array}$ & $\begin{array}{l}7532 \\
\text { (vacc) } \\
7151 \text { (ctrl) } \\
\end{array}$ & $\begin{array}{l}0 \text { (vacc) } \\
1 \text { (ctrl) }\end{array}$ & $\begin{array}{l}68 \\
(-677,99)\end{array}$ & $\begin{array}{l}1 \text { (vacc) } \\
0(\text { ctrl })\end{array}$ & $\begin{array}{l}-185 \\
(-900,88)\end{array}$ \\
\hline $\begin{array}{l}\text { South African } \\
\text { HIV- efficacy } \\
{[17,38]^{a}}\end{array}$ & 9vCRM & $6,10,14$ wks & $\begin{array}{l}\text { IPD after } \\
3 \text { doses }\end{array}$ & $\begin{array}{l}6 w k \\
\text { to } 6.2 \\
y\end{array}$ & $\begin{array}{l}18633 \\
\text { (vacc) } \\
18626 \\
\text { (ctrl) }\end{array}$ & $\begin{array}{l}0 \text { (vacc) } \\
1 \text { (ctrl) }\end{array}$ & $\begin{array}{l}67 \\
(-718,99)\end{array}$ & $\begin{array}{l}3 \text { (vacc) } 1 \\
\text { (ctrl) }\end{array}$ & $\begin{array}{l}-200 \\
(-900,69)\end{array}$ \\
\hline $\begin{array}{l}\text { South African HIV } \\
+ \text { efficacy }[17,38]^{a}\end{array}$ & $9 \mathrm{vCRM}$ & $6,10,14$ wks & $\begin{array}{l}\text { IPD after } \\
3 \text { doses }\end{array}$ & $\begin{array}{l}6 w k \\
\text { to } 6.2 \\
y\end{array}$ & $\begin{array}{l}1289 \\
\text { (vacc) } \\
1288 \text { (ctrl) } \\
\end{array}$ & $\begin{array}{l}5 \text { (vacc) } \\
3 \text { (ctrl) }\end{array}$ & $\begin{array}{l}-67 \\
(-595,60)\end{array}$ & $\begin{array}{l}3 \text { (vacc) } \\
6 \text { (ctrl) }\end{array}$ & $\begin{array}{l}50 \\
(-99,88)\end{array}$ \\
\hline $\begin{array}{l}\text { Gambia efficacy } \\
{[14,39]^{a}}\end{array}$ & $9 \mathrm{VCRM}$ & $6,10,14$ wks & $\begin{array}{l}\text { IPD after } \\
3 \text { doses }\end{array}$ & $\begin{array}{l}6 w k \\
\text { to } 2.9 \\
y\end{array}$ & $\begin{array}{l}8718 \\
\text { (vacc) } \\
8719 \text { (ctrl) } \\
\end{array}$ & $\begin{array}{l}0 \text { (vacc) } \\
2 \text { (ctrl) }\end{array}$ & $\begin{array}{l}80 \\
(-317,99)\end{array}$ & $\begin{array}{l}6 \text { (vacc) } \\
7 \text { (ctrl) }\end{array}$ & $\begin{array}{l}14 \\
(-155,71)\end{array}$ \\
\hline $\begin{array}{l}\text { Meta-analysis of } \\
\text { preceding efficacy } \\
\text { studies }\left({ }^{a}\right)\end{array}$ & $\begin{array}{c}7 V C R M \\
\& \\
9 \vee C R M\end{array}$ & \multicolumn{2}{|c|}{ see individual studies } & & $\begin{array}{l}55099 \\
(\text { vacc) } \\
54725 \\
\text { (ctrl) }\end{array}$ & $\begin{array}{l}7 \text { (vacc) } \\
20 \text { (ctrl) }\end{array}$ & $\begin{array}{l}61 \\
(13,82)\end{array}$ & $\begin{array}{l}13 \text { (vacc) } \\
15 \text { (ctrl) }\end{array}$ & $\begin{array}{l}13 \\
(-79,58)\end{array}$ \\
\hline $\begin{array}{l}\text { US post- } \\
\text { marketing } \\
\text { surveillance [19] }\end{array}$ & 7VCRM & $\begin{array}{l}\text { 2,4,6,12-15 mo; } \\
\text { catch-up } \\
\text { schedule for < } 2 \\
\text { y }\end{array}$ & $\begin{array}{l}\text { IPD }\left(2^{\text {nd }}\right. \\
\text { yr after } \\
\text { launch })\end{array}$ & $\begin{array}{l}>2 y \\
\text { (not all } \\
\text { vacc) }\end{array}$ & $\sim 433,000$ & $\begin{array}{l}79 \text { (pre) } \\
14 \text { (post) }\end{array}$ & $\begin{array}{l}83 \\
(72,90) \\
\text { (\% decrease decrease } \\
\text { in estimated rate } \\
\text { from pre-7VCRM) }\end{array}$ & $\begin{array}{l}20 \text { (pre) } \\
12 \text { (post) }\end{array}$ & $\begin{array}{l}40 \\
(-5,68) \\
\text { (\% decrease in } \\
\text { estimated rate } \\
\text { from pre-7VCRM) }\end{array}$ \\
\hline $\begin{array}{l}\text { US CDC case- } \\
\text { control [9] }\end{array}$ & $7 V C R M$ & $2,4,6,12-15 \mathrm{mo}$ & $\begin{array}{l}I P D \geq 1 \\
\text { dose }\end{array}$ & $\begin{array}{l}3 \text { to } 59 \\
\text { mo }\end{array}$ & n.a. & $\begin{array}{l}34 \\
\text { discordant } \\
\text { sets }\end{array}$ & $\begin{array}{l}87 \\
(65,95)\end{array}$ & $\begin{array}{l}46 \\
\text { discordant } \\
\text { sets }\end{array}$ & $\begin{array}{l}26 \\
(-45,62)\end{array}$ \\
\hline $\begin{array}{l}\text { Canada (Québec) } \\
\text { [40]: case-control }\end{array}$ & $7 V C R M$ & $2,4,12 \mathrm{mo}$ & $\begin{array}{l}I P D \geq 1 \\
\text { dose }\end{array}$ & $<5 y$ & n.a. & $\begin{array}{l}3 \text { (vacc); } 8 \\
\text { (unvacc) }\end{array}$ & $93(61,99)$ & $\begin{array}{l}29 \text { (vacc); } \\
8 \text { (unvacc) }\end{array}$ & $\begin{array}{l}42 \\
(-76,79) \\
\end{array}$ \\
\hline \multicolumn{3}{|c|}{ Conjugate Vaccines } & $\mathrm{AOM}$ & & & & & & \\
\hline $\begin{array}{l}\text { Finland [10]: } \\
\text { efficacy (FinOM) }\end{array}$ & $7 V C R M$ & $2,4,6,12 \mathrm{mo}$ & $\begin{array}{l}\text { AOM } \\
\text { after } \geq 3 \\
\text { doses }\end{array}$ & $\begin{array}{l}6.5 \text { to } \\
24 \mathrm{mo}\end{array}$ & $\begin{array}{l}831 \text { (vacc) } \\
831 \text { (ctrl) }\end{array}$ & $\begin{array}{l}43 \text { (vacc) } \\
58 \text { (ctrl) }\end{array}$ & $\begin{array}{l}25 \\
(-14,51)\end{array}$ & $\begin{array}{l}17 \text { (vacc) } \\
26 \text { (ctrl) }\end{array}$ & $\begin{array}{l}34 \\
(-26,65)\end{array}$ \\
\hline $\begin{array}{l}\text { Finland [41]: } \\
\text { efficacy(FinOM) }\end{array}$ & $7 \mathrm{VOMP}$ & $2,4,6,12 \mathrm{mo}$ & $\begin{array}{l}\text { AOM } \\
\text { after } \geq 3 \\
\text { doses }\end{array}$ & $\begin{array}{l}6.5 \text { to } \\
24 \mathrm{mo}\end{array}$ & $\begin{array}{l}831 \text { (vacc) } \\
831 \text { (ctrl) }\end{array}$ & $\begin{array}{l}37 \text { (vacc) } \\
58 \text { (ctrl) }\end{array}$ & $\begin{array}{l}37 \\
(1,59)\end{array}$ & $\begin{array}{l}22 \text { (vacc) } \\
26 \text { (ctrl) }\end{array}$ & $\begin{array}{l}16 \\
(-53,54)\end{array}$ \\
\hline $\begin{array}{l}\text { Czech/Slovak [1 1]: } \\
\text { efficacy (POET) }\end{array}$ & $\begin{array}{l}11 \mathrm{Pn}- \\
\mathrm{PD}\end{array}$ & $3,4,5,12-15 \mathrm{mo}$ & $\begin{array}{l}\text { AOM } \\
\text { after } \geq 3 \\
\text { doses }\end{array}$ & $\begin{array}{l}5 \text { to } 27 \\
\text { mo }\end{array}$ & $\begin{array}{l}2489 \\
\text { (vacc) } \\
2479 \text { (ctrl) }\end{array}$ & $\begin{array}{l}24 \text { (vacc) } \\
43 \text { (ctrl) }\end{array}$ & $\begin{array}{l}44 \\
(8,66)\end{array}$ & $\begin{array}{l}1 \text { (vacc) } \\
3 \text { (ctrl) }\end{array}$ & $\begin{array}{l}67 \\
(-209,97)\end{array}$ \\
\hline
\end{tabular}

*PS14-V, 14 valent polysaccharide vaccine, contained 19F but not 19A; it was replaced in the early 1980s by the 23 -valent vaccine containing both $19 \mathrm{~A}$ and $19 \mathrm{~F}$

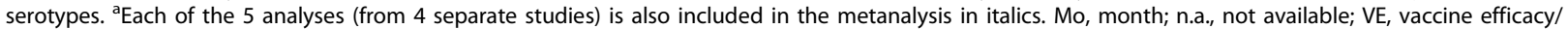
effectiveness; wk, week; $y$, year; vacc, active vaccine group; unvacc, unvaccinated; ctrl, control; 7vCRM, 7-valent conjugate vaccine with CRM197 carrier; 9vCRM, 9valent conjugate vaccine candidate with CRM197 carrier; 7vOMP, 7-valent conjugate vaccine candidate with outer membrane protein carrier; IPD, invasive pneumococcal disease; AOM, acute otitis media 
Table 2 Studies examining efficacy or effectiveness of 19F-containing vaccines against 19A carriage

\begin{tabular}{|c|c|c|c|c|c|c|c|c|}
\hline $\begin{array}{l}\text { Study \& } \\
\text { location }\end{array}$ & Vaccine & $\begin{array}{l}\text { Vaccine } \\
\text { regimen }\end{array}$ & $\begin{array}{l}\text { Age group(s) } \\
\text { sampled }\end{array}$ & $\begin{array}{l}\text { Number } \\
\text { of } \\
\text { Subjects }\end{array}$ & $\begin{array}{l}\text { Number } \\
\text { of } 19 \mathrm{~F} \\
\text { isolates }\end{array}$ & $\begin{array}{l}\text { Efficacy against } 19 \mathrm{~F} \\
\text { VE or OR } \\
\text { ( } 95 \% \mathrm{Cl} \text { or } p \text { value) }\end{array}$ & $\begin{array}{l}\text { Number } \\
\text { of } 19 \mathrm{~A} \\
\text { isolates }\end{array}$ & $\begin{array}{l}\text { Efficacy against } \\
19 \mathrm{~A} \\
\text { VE or OR } \\
\text { (95\% Cl or } p \\
\text { value) }\end{array}$ \\
\hline $\begin{array}{l}\text { South Africa [42]: } \\
\text { double blind, } \\
\text { randomized, } \\
\text { efficacy }\end{array}$ & $9 \mathrm{vCRM}$ & $6,10,14$ wk & $9 \mathrm{mo}$ & $\begin{array}{l}242 \text { (vacc) } \\
239 \text { (ctrl) }\end{array}$ & $\begin{array}{l}19 \text { (vacc) } \\
32 \text { (ctrl) }\end{array}$ & VE $42 \% *(p=0.05)$ & $\begin{array}{l}7 \text { (vacc) } \\
11 \text { (ctrl) }\end{array}$ & VE 37\%* (NS) \\
\hline $\begin{array}{l}\text { Israel [43]: double } \\
\text { blind, } \\
\text { randomized } \\
\text { efficacy }\end{array}$ & $9 \mathrm{VCRM}$ & $\begin{array}{l}12-24 \text { mo } \\
\text { received } 2 \\
\text { doses; } \geq 24 \\
\text { mo } 1 \text { dose }\end{array}$ & $\begin{array}{l}15-35 \text { mo } 36-\geq \\
48 \text { mo }\end{array}$ & $\begin{array}{l}816 \text { (vacc) } \\
790 \text { (ctrl) } \\
1071 \\
\text { (vacc) } \\
1073 \text { (ctrl) }\end{array}$ & $\begin{array}{l}41 \text { (vacc) } \\
62 \text { (ctrl) } \\
57 \text { (vacc) } \\
52 \text { (ctrl) }\end{array}$ & $\begin{array}{l}\text { OR } 0.58(p=0.08) \\
\text { OR } 1.11(p=0.69)\end{array}$ & $\begin{array}{l}\text { n.a. }=113 \\
\text { total (all } \\
\text { groups } \\
\text { combined) }\end{array}$ & $\begin{array}{l}\text { OR } 0.60^{* *}(p=0.38) \\
\text { OR } 1.25^{* *}(p=0.56)\end{array}$ \\
\hline $\begin{array}{l}\text { US Navajo } \\
\text { Apache [21]: } \\
\text { double blind, } \\
\text { randomized } \\
\text { efficacy }\end{array}$ & $7 \mathrm{VCRM}$ & $\begin{array}{l}2,4,6,12-15 \mathrm{mo} \\
(87 \%)\end{array}$ & $\begin{array}{l}1-7 \text { y (median } \\
3.3 y) \\
\text { All }>12 \text { mo } \\
\text { since last dose }\end{array}$ & $\begin{array}{l}468 \text { (vacc) } \\
281 \text { (ctrl) }\end{array}$ & $\begin{array}{l}24 \text { (vacc) } \\
16 \text { (ctrl) }\end{array}$ & OR 0.89 (0.47-1.72) & $\begin{array}{l}12 \text { (vacc) } \\
10 \text { (ctrl) }\end{array}$ & OR 0.71 (0.30-1.67) \\
\hline $\begin{array}{l}\text { US Navajo } \\
\text { Apache [23]: } \\
\text { double blind, } \\
\text { randomized }\end{array}$ & 7VCRM & $2,4,6,12-15 \mathrm{mo}$ & $7 \mathrm{mo}$ & $\begin{array}{l}227 \text { (vacc) } \\
226 \text { (ctrl) }\end{array}$ & $\begin{array}{l}2 \text { (vacc) } \\
11 \text { (ctrl) }\end{array}$ & $\begin{array}{l}\text { OR not calculated } \\
\text { because "small sample } \\
\text { size resulted in non- } \\
\text { convergence of model" }\end{array}$ & $\begin{array}{l}10 \text { (vacc) } \\
4 \text { (ctrl) }\end{array}$ & OR $1.75(0.41-7.58)$ \\
\hline
\end{tabular}
efficacy

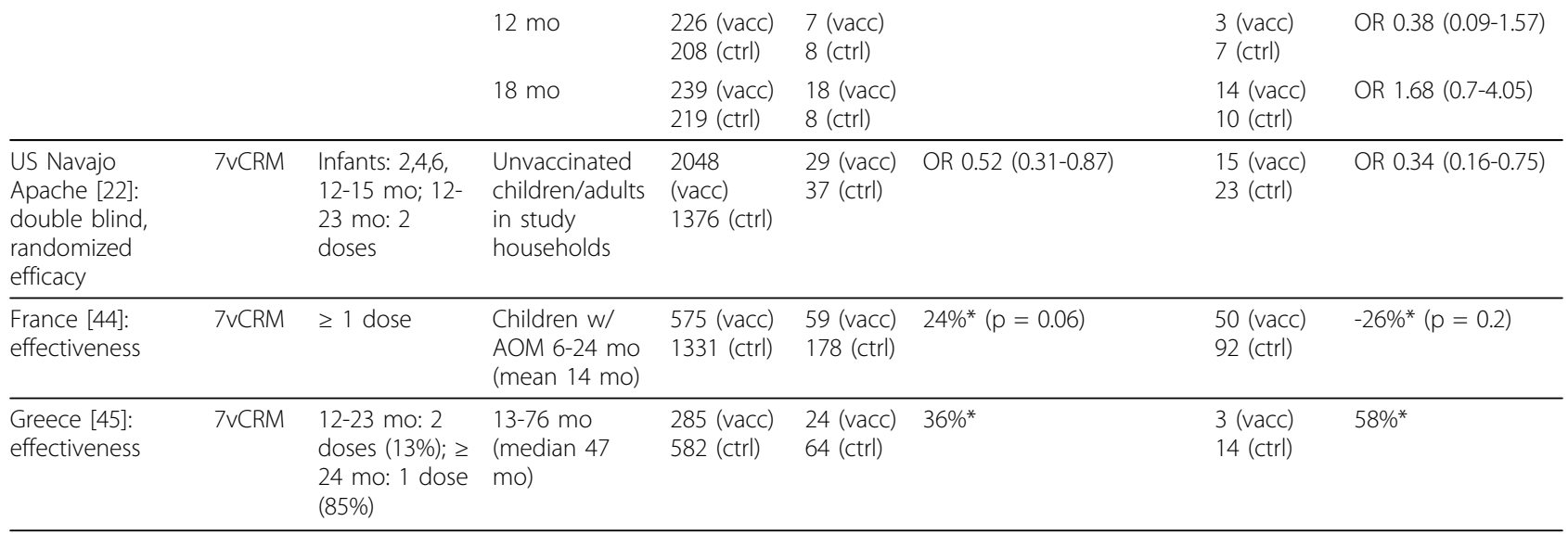

*Only case numbers provided in original paper; approximate \% VE calculated for this table;

** confidence intervals for odds rations not provided in original publication.

Mo, month; NS; not significant; OR, odds ratio; VE, vaccine efficacy/effectiveness; wk, week; y, year. 7vCRM, 7-valent conjugate vaccine with CRM197 carrier. 9vCRM; 9-valent conjugate vaccine candidate with CRM197 carrier.

apparent increase in 19A carriage is observed (odds ratios greater than 1 or negative point estimates for efficacy) following vaccination, although these changes were generally not statistically significant [22]. This suggests that any effect of 7vCRM on 19A may be limited to prevention of disease once colonized, but not on preventing $19 \mathrm{~A}$ colonization in the first place.

\section{Immunogenicity data}

The ability of pneumococcal vaccines to induce functional anti-capsular polysaccharide antibodies is considered to be the major mechanism by which these vaccines prevent IPD [24,25]. Vaccine-induced antibody levels measured by ELISA [25] and especially by opsonophagocytic activity assays (OPA) against individual pneumococcal serotypes have been shown to correlate well with clinical effectiveness [26]. Henckaerts et al. [24] showed that, following three primary doses of $7 \mathrm{vCRM}$, virtually no child (3\%) developed anti-19A OPA above the threshold suggested to correlate with clinical effectiveness against IPD (i.e., OPA titer $\geq 8$ ) $[25,26]$. More recent studies from three different laboratories are consistent with these findings [27-29]. In contrast, a booster dose, of 7vCRM elicited some anti-19A OPA activity, with approximately $25 \%-30 \%$ of children having OPA titers $\geq 8[29,30]$.

Other pneumococcal conjugate vaccines with distinct chemistries and carriers may have different immunological properties. For example, it has been observed that the periodate oxidation step used to link the $19 \mathrm{~F}$ 
polysaccharide to the $\mathrm{CRM}_{197}$ carrier protein in $7 \mathrm{vCRM}$ prior to reductive amination alters the antigenicity of the polysaccharide [31]. In three separate studies [29,30,32], $20 \%-30 \%$ of children receiving a 3 -dose primary series of PHiD-CV (a recently licensed 10-valent pneumococcal non-typeable $H$. influenzae protein Dconjugate vaccine in which $19 \mathrm{~F}$ is conjugated to diphtheria toxoid; Synflorix ${ }^{\mathrm{mw}}$, GlaxoSmithKline Biologicals) had 19A OPA titers $\geq 8$, compared with fewer than $5 \%$ of $7 \mathrm{vCRM}$-immunized children in the same studies. Furthermore, a booster dose in the second year of life led to 19A OPA titers above this level in approximately $50 \%$ of PHiD-CV-immunized children and $30 \%$ of 7vCRM-immunized children [29,30].

Differences in OPA levels may reflect variability not only in the quantity, but also in the quality of the antibodies elicited by different conjugates. Nurkka et al. studied the functionality of cross-reactive antibodies induced by 7vCRM, 7vOMPC (polysaccharides conjugated to outer membrane proteins from Neisseria meningitidis, Merck Sharpe \& Dohme), and 11Pn-PD, each with 19F conjugated to different carrier proteins [33]. In serum samples selected to have similar antibody concentrations as measured by ELISA, the 19A OPA titers were higher in the 11Pn-PD group than in the two other groups [33].

\section{Conclusion}

The clinical efficacy, effectiveness, and immunogenicity studies summarized here suggest that immunization with 19F-containing pneumococcal conjugate vaccines can provide some direct protection against 19A disease. Nonetheless, the limited anti-19A activity of 7vCRM in particular, which appears insufficient to prevent 19A colonization, was evidently also insufficient to prevent or reverse [5] a net rise in 19A disease in young children in countries where high antimicrobial use has led to greatly increased colonization by antibiotic non-susceptible strains, including certain clones of 19A [5,34-36]. This does not exclude the possibility, however, that the modest effect of $7 \mathrm{vCRM}$ on disease may have attenuated or slowed down the rise. In any case, a protective effect of $7 \mathrm{vCRM}$ against $19 \mathrm{~A}$ is likely to be most readily detectable in fully immunized children following a booster dose, and unfortunately, much of the IPD burden occurs prior to that time [19]. On the other hand, certain vaccines with different conjugation methods and carrier proteins have shown immunological cross-reactivity against 19A, even following a primary dose series, and could conceivably show greater protection against disease. Whether they offer any protection against 19A colonization remains to be determined. Accordingly, the potential for clinically significant cross-protection against 19A (and 6A) disease needs to be independently considered for each new vaccine.

\section{Methods}

To systematically assess the clinical efficacy or effectiveness of 19F-containing vaccines against 19A disease or nasopharyngeal carriage, we searched for English-language articles in the electronic databases PubMed, Current contents, Scopus, and Embase from 1985 to 2008, with the latest search conducted 15 May 2009. The keywords used were "S pneumoniae" "19A", "19 A", "pneumococcal vaccine [MeSH Terms]", "carriage", "colonization", "invasive pneumococcal disease", and "acute otitis media." In addition, we also consulted recent reviews describing clinical trial results on nasopharyngeal carriage with $7 \mathrm{vCRM}$ for further references and, where possible, searched abstracts from major infectious diseases meetings in 2008 and the first half of 2009. For studies on disease, we only included reports in which the authors themselves provided vaccine efficacy or effectiveness calculations for 19A. The results are summarized in tabular format in lieu of a formal metanalysis, as the latter was considered inappropriate due to the large variability in study design (efficacy or effectiveness), vaccine dosing schedule, vaccines used, and disease endpoints (IPD, AOM). Because there were relatively few reports of vaccine effect on 19A nasopharyngeal carriage that included vaccine efficacy or effectiveness calculations, we also included studies where we could make those calculations based on case numbers.

\section{- Summary}

- Since the introduction of the 7-valent pneumococcal conjugate vaccine $(7 \mathrm{vCRM})$, a rise in serotype 19A disease has been observed in the US and some other countries with high antibiotic use, and this has been taken to indicate that the $19 \mathrm{~F}$ conjugate included in the vaccine does not provide any crossprotection against serotype 19A.

- However, clinical and post-licensure studies with several 19F-containing vaccines, including 7vCRM, consistently report modest clinical cross-protection against 19A disease in fully immunized individuals.

- Consistent with this finding, 7vCRM elicits anti19A functional antibody responses that are detectable after the booster dose.

- New pneumococcal conjugate vaccines using different conjugation methods or carrier proteins which elicit earlier and/or higher functional anti-19A antibody responses could be more cross-protective against 19A disease than 7vCRM.

\section{Footnote}

Prevenar/Prevnar is a trademark of Wyeth Vaccines.

Synflorix is a trademark of GlaxoSmithKline group of companies. 


\section{Acknowledgements}

The authors thank Dr Frederik Fierens (GlaxoSmithKline Biologicals, Belgium) for critically reading the manuscript. Writing assistance was provided by $\mathrm{Dr}$ Julie Harriague (4clinics, France) and manuscript coordination by Dr Valentine Wascotte (GlaxoSmithKline Biologicals, Belgium).

\section{Authors' contributions}

WPH reviewed the literature and, together with $B H$ and $L S$, analyzed the data and wrote the manuscript. All authors read and approved the final manuscript.

\section{Competing interests}

Financial support: GlaxoSmithKline Biologicals paid for all costs associated with the development and the publishing of the present manuscript. The corresponding author had full access to the data and final responsibility for submission of the publication.

Competing interests: Drs. Hausdorff, Hoet and Schuerman declare they are employed and own stock in GlaxoSmithKline Biologicals, which has a licensed pneumococcal conjugate vaccine.

Received: 14 May 2009

Accepted: 2 February 2010 Published: 2 February 2010

\section{References}

1. Pelton SI, Huot H, Finkelstein JA, Bishop CJ, Hsu KK, Kellenberg J, Huang SS, Goldstein R, Hanage WP: Emergence of 19A as virulent and multidrug resistant Pneumococcus in Massachusetts following universal immunization of infants with pneumococcal conjugate vaccine. Pediatr Infect Dis J 2007, 26(6):468-472.

2. Singleton RJ, Hennessy TW, Bulkow LR, Hammitt LL, Zulz T, Hurlburt DA, Butler JC, Rudolph K, Parkinson A: Invasive pneumococcal disease caused by nonvaccine serotypes among alaska native children with high levels of 7-valent pneumococcal conjugate vaccine coverage. JAMA 2007, 297(16):1784-1792.

3. Hicks LA, Harrison LH, Flannery B, Hadler JL, Schaffner W, Craig AS, Jackson $D$, Thomas A, Beall B, Lynfield $R$, et al: Incidence of pneumococcal disease due to non-pneumococcal conjugate vaccine (PCV7) serotypes in the United States during the era of widespread PCV7 vaccination, 1998-2004. J Infect Dis 2007, 196(9):1346-1354.

4. Kyaw MH, Lynfield R, Schaffner W, Craig AS, Hadler J, Reingold A, Thomas AR, Harrison LH, Bennett NM, Farley MM, et al: Effect of introduction of the pneumococcal conjugate vaccine on drug-resistant Streptococcus pneumoniae. N Engl J Med 2006, 354(14):1455-1463.

5. Moore MR, Gertz RE, Woodbury RL Jr, Barkocy-Gallagher GA, Schaffner W, Lexau C, Gershman K, Reingold A, Farley M, Harrison LH, et al: Population snapshot of emergent Streptococcus pneumoniae serotype 19A in the United States, 2005. J Infect Dis 2008, 197(7):1016-1027.

6. Pai R, Moore MR, Pilishvili T, Gertz RE, Whitney CG, Beall B: Postvaccine genetic structure of Streptococcus pneumoniae serotype 19A from children in the United States. J Infect Dis 2005, 192(11):1988-1995.

7. Robbins JB, Austrian R, Lee CJ, Rastogi SC, Schiffman G, Henrichsen J, Makela PH, Broome CV, Facklam RR, Tiesjema RH, et al: Considerations for formulating the second-generation pneumococcal capsular polysaccharide vaccine with emphasis on the cross-reactive types within groups. J Infect Dis 1983, 148(6):1136-1159.

8. Park SY, Moore MR, Bruden DL, Hyde TB, Reasonover AL, Harker-Jones M, Rudolph KM, Hurlburt DA, Parks DJ, Parkinson AJ, et al: Impact of conjugate vaccine on transmission of antimicrobial-resistant Streptococcus pneumoniae among Alaskan children. Pediatr Infect Dis J 2008, 27(4):335-340.

9. Whitney CG, Pilishvili T, Farley MM, Schaffner W, Craig AS, Lynfield R, Nyquist AC, Gershman KA, Vazquez M, Bennett NM, et al: Effectiveness of seven-valent pneumococcal conjugate vaccine against invasive pneumococcal disease: a matched case-control study. Lancet 2006, 368(9546):1495-1502.

10. Eskola J, Kilpi T, Palmu A, Jokinen J, Haapakoski J, Herva E, Takala A, Kayhty H, Karma P, Kohberger R, et al: Efficacy of a pneumococcal conjugate vaccine against acute otitis media. N Engl J Med 2001, 344(6):403-409.

11. Prymula R, Peeters P, Chrobok V, Kriz P, Novakova E, Kaliskova E, Kohl I, Lommel P, Poolman J, Prieels JP, et al: Pneumococcal capsular polysaccharides conjugated to protein $D$ for prevention of acute otitis media caused by both Streptococcus pneumoniae and non-typable Haemophilus influenzae: a randomised double-blind efficacy study. Lancet 2006, 367(9512):740-748.

12. Jakobsen H, Sigurdsson VD, Sigurdardottir S, Schulz D, Jonsdottir I: Pneumococcal serotype $19 \mathrm{~F}$ conjugate vaccine induces cross-protective immunity to serotype $19 \mathrm{~A}$ in a murine pneumococcal pneumonia model. Infect Immun 2003, 71(5):2956-2959.

13. Dagan R, Givon-Lavi N, Janco J, Greenberg D: Nasopharyngeal Carriage of S. pneumoniae Vaccine Serotypes (VT-Sp) in First 2 Years of Life Following 4 Different 7-Valent CRM Conjugate Vaccine (PCV7) Schedules. 6th International Symposium on Pneumococci and Pneumoccocal Diseases: 8-12 June 2008 2008; Reykjavik, Iceland 2008.

14. Klugman KP, Cutts F, Adegbola RA, Black S, Madhi SA, O'Brien KL, Santosham M, Shinefield H, Sterne JAC, et al: Meta-analysis of the efficacy of conjugate vaccines against invasive pneumococcal disease. Pneumococcal Vaccines: the impact of conjugate vaccine Washington, DC.: ASM PressSiber GR, et al 2008.

15. Black S, Shinefield H, Fireman B, Lewis E, Ray P, Hansen JR, Elvin L, Ensor KM, Hackell J, Siber G, et al: Efficacy, safety and immunogenicity of heptavalent pneumococcal conjugate vaccine in children. Northern California Kaiser Permanente Vaccine Study Center Group. Pediatr Infect Dis J 2000, 19(3):187-195.

16. O'Brien KL, Moulton LH, Reid R, Weatherholtz R, Oski J, Brown L, Kumar G, Parkinson A, Hu D, Hackell J, et al: Efficacy and safety of seven-valent conjugate pneumococcal vaccine in American Indian children: group randomised trial. Lancet 2003, 362(9381):355-361.

17. Madhi SA, Adrian $P$, Kuwanda L, Jassat W, Jones S, Little T, Soininen A, Cutland C, Klugman KP: Long-term immunogenicity and efficacy of a 9valent conjugate pneumococcal vaccine in human immunodeficient virus infected and non-infected children in the absence of a booster dose of vaccine. Vaccine 2007, 25(13):2451-2457.

18. Cutts FT, Zaman SM, Enwere G, Jaffar S, Levine OS, Okoko JB, Oluwalana C, Vaughan A, Obaro SK, Leach A, et al: Efficacy of nine-valent pneumococcal conjugate vaccine against pneumonia and invasive pneumococcal disease in The Gambia: randomised, double-blind, placebo-controlled trial. Lancet 2005, 365(9465):1139-1146.

19. Whitney CG, Farley MM, Hadler J, Harrison LH, Bennett NM, Lynfield R, Reingold A, Cieslak PR, Pilishvili T, Jackson D, et al: Decline in invasive pneumococcal disease after the introduction of protein-polysaccharide conjugate vaccine. N Engl J Med 2003, 348(18):1737-1746.

20. CDC: Notice to readers: Updated recommendations on the use of pneumococcal conjugate vaccine in a setting of vaccine shortageAdvisory Committee on Immunization Practices. MMWR Morb Mortal Wkly Rep 2001, 50(50):1140-1142.

21. Millar EV, O'Brien KL, Watt JP, Bronsdon MA, Dallas J, Whitney CG, Reid R, Santosham M: Effect of community-wide conjugate pneumococcal vaccine use in infancy on nasopharyngeal carriage through 3 years of age: a cross-sectional study in a high-risk population. Clin Infect Dis 2006, 43(1):8-15.

22. Millar EV, Watt JP, Bronsdon MA, Dallas J, Reid R, Santosham M, O'Brien KL: Indirect effect of 7-valent pneumococcal conjugate vaccine on pneumococcal colonization among unvaccinated household members. Clin Infect Dis 2008, 47(8):989-996.

23. O'Brien KL, Millar EV, Zell ER, Bronsdon M, Weatherholtz R, Reid R, Becenti J, Kvamme S, Whitney CG, Santosham M: Effect of pneumococcal conjugate vaccine on nasopharyngeal colonization among immunized and unimmunized children in a community-randomized trial. $J$ Infect Dis 2007, 196(8):1211-1220.

24. Henckaerts I, Durant N, De Grave D, Schuerman L, Poolman J: Validation of a routine opsonophagocytosis assay to predict invasive pneumococcal disease efficacy of conjugate vaccine in children. Vaccine 2007, 25(13):2518-2527.

25. World Health Organization: Recommendations for the production and control of pneumococcal conjugate vaccines. WHO Technical Report Series. Annex 2 Geneva, Switzerland: World Health Organization 2005, 927.

26. Prymula $R$, Schuerman $L: 10$-valent pneumococcal nontypeable Haemophilus influenzae PD conjugate vaccine: Synflorix. Expert Rev Vaccines 2009, 8(11):1479-1500.

27. Kieninger DM, Kueper K, Steul K, Juergens C, Ahlers N, Baker S, Giardina P, Gruber W, Scott D: Safety and immunologic non-inferiority of 13-valent 
pneumococcal conjugate vaccine compared to 7-valent pneumococcal conjugate vaccine given as a 4-dose series with routine vaccines in healthy infants and toddlers. 48th Interscience Conference on Antimicrobial Agents \& Chemotherapy (ICAAC). Washington DC, USA 2008.

28. Lee $\mathrm{H}$, Nahm MH, Burton $\mathrm{R}$, Kim KH: Immune response in infants of the heptavalent pneumococcal conjugate vaccine against vaccine-related serotypes 6A and 19A. Clin Vaccine Immunol 2009.

29. Vesikari T, Wysocki J, Chevallier B, Karvonen A, Czajka H, Arsène J-P, Lommel P, Dieussaert I, Schuerman L: Immunogenicity of the 10-valent pneumococcal non-typeable Haemophilus influenzae Protein $D$ Conjugate Vaccine (PHiD-CV) compared to the licensed 7vCRM vaccine. Pediatr Infect Dis J 2009, 28(4 Suppl):S66-76.

30. Wysocki J, Tejedor JC, Grunert D, Konior R, Garcia-Sicilia J, Knuf M, Bernard L, Dieussaert I, Schuerman L: Immunogenicity of the 10-valent pneumococcal non-typeable Haemophilus influenzae Protein D Conjugate Vaccine (PHiD-CV) when co-administered with different Neisseria meningitidis serogroup C conjugate vaccines. Pediatr Infect Dis J 2009, 28(4 Suppl):S77-88.

31. Concepcion N, Lee C-H, Frasch CE: Conjugation chemistry effects immunological reactivity and epitope expression of the pneumococcal 19F polysaccharide. 3rd International Symposium on Pneumococci and Pneumoccocal Diseases Anchorage, Alaska 2002.

32. Bermal N, Szenborn L, Chrobot A, Alberto E, Lommel P, Gatchalian S, Dieussaert I, Schuerman L: The 10-valent pneumococcal non-typeable Haemophilus influenzae Protein D conjugate vaccine (PHiD-CV) coadministered with DTPW-HBV/Hib and poliovirus vaccines: assessment of immunogenicity. Pediatr Infect Dis J 2009, 28(4 Suppl):S89-96.

33. Nurkka A, Lehtonen $H$, Vuorela A, Ekstrom N, Kayhty $H$ : Functionality of antibodies against serotypes $6 \mathrm{~A}$ and $19 \mathrm{~A}$ induced by three different pneumococcal conjugate vaccines (PCV) in infants. 5th International Symposium on Pneumococci and Pneumoccocal Diseases: 2-6 April 2006 2006; Alice Springs, Australia 2006.

34. Van Effelterre T, Moore M, Whitney C, Fierens F, Hausdorff W: A Dynamic Transmission Model of Invasive Pneumococcal Disease (IPD): Implications for Serotype 19A. 48th Interscience Conference on Antimicrobial Agents \& Chemotherapy (ICAAC). Washington DC, USA 2008.

35. Dagan R, Givon-Lavi N, Leibovitz E, Greenberg D, Porat N: Introduction and Proliferation of Multidrug-Resistant Streptococcus pneumoniae Serotype 19A Clones That Cause Acute Otitis Media in an Unvaccinated Population. J Infect Dis 2009, 199(6):776-85.

36. Hwa Choi E, Hee Kim S, Wook Eun B, Jung Kim S, Hee Kim N, Lee J, Jong Lee $\mathrm{H}$ : Streptococcus pneumoniae serotype 19A in children, South Korea. Emerg Infect Dis 2008, 14(2):275-281.

37. Butler JC, Breiman RF, Campbell JF, Lipman HB, Broome CV, Facklam RR: Pneumococcal polysaccharide vaccine efficacy. An evaluation of current recommendations. JAMA 1993, 270(15):1826-1831.

38. Klugman KP, Walsh AL, Phiri A, Molyneux EM: Mortality in penicillinresistant pneumococcal meningitis. Pediatr Infect Dis J 2008, 27(7):671-672.

39. Saaka M, Okoko BJ, Kohberger RC, Jaffar S, Enwere G, Biney EE, Oluwalana C, Vaughan A, Zaman SM, Asthon L, et al: Immunogenicity and serotype-specific efficacy of a 9-valent pneumococcal conjugate vaccine (PCV-9) determined during an efficacy trial in The Gambia. Vaccine 2008, 26(29-30):3719-3726

40. Deceuninck $G$, De Wals $P$, De Serres $G$, Boulianne N: Effectiveness of pneumococcal conjugate vaccine using a $2+1$ infant schedule in Quebec, Canada.. Pediatr Infect Dis J 2010.

41. Kilpi T, Ahman H, Jokinen J, Lankinen KS, Palmu A, Savolainen H, Gronholm M, Leinonen M, Hovi T, Eskola J, et al: Protective efficacy of a second pneumococcal conjugate vaccine against pneumococcal acute otitis media in infants and children: randomized, controlled trial of a 7valent pneumococcal polysaccharide-meningococcal outer membrane protein complex conjugate vaccine in 1666 children. Clin Infect Dis 2003, 37(9):1155-1164

42. Mbelle N, Huebner RE, Wasas AD, Kimura A, Chang I, Klugman KP: Immunogenicity and impact on nasopharyngeal carriage of a nonavalent pneumococcal conjugate vaccine. J Infect Dis 1999, 180(4):1171-1176.

43. Dagan R, Givon-Lavi N, Zamir O, Sikuler-Cohen M, Guy L, Janco J, Yagupsky P, Fraser D: Reduction of nasopharyngeal carriage of Streptococcus pneumoniae after administration of a 9-valent pneumococcal conjugate vaccine to toddlers attending day care centers. J Infect Dis 2002, 185(7):927-936.

44. Cohen R, Levy C, de La Rocque F, Gelbert N, Wollner A, Fritzell B, Bonnet E, Tetelboum R, Varon E: Impact of pneumococcal conjugate vaccine and of reduction of antibiotic use on nasopharyngeal carriage of nonsusceptible pneumococci in children with acute otitis media. Pediatr Infect Dis J 2006, 25(11):1001-1007.

45. Grivea IN, Panagiotou M, Tsantouli AG, Syrogiannopoulos GA: Impact of heptavalent pneumococcal conjugate vaccine on nasopharyngeal carriage of penicillin-resistant Streptococcus pneumoniae among daycare center attendees in central Greece. Pediatr Infect Dis J 2008, 27(6):519-525.

\section{Pre-publication history}

The pre-publication history for this paper can be accessed here:http://www biomedcentral.com/1471-2431/10/4/prepub

doi:10.1186/1471-2431-10-4

Cite this article as: Hausdorff et al:: Do pneumococcal conjugate vaccines provide any cross-protection against serotype 19A?. BMC Pediatrics 2010 10:4.

\section{Submit your next manuscript to BioMed Central and take full advantage of:}

- Convenient online submission

- Thorough peer review

- No space constraints or color figure charges

- Immediate publication on acceptance

- Inclusion in PubMed, CAS, Scopus and Google Scholar

- Research which is freely available for redistribution

Submit your manuscript at www.biomedcentral.com/submit
C) Biomed Central 